\title{
Chechnya: The War Without An End
}

\author{
Alexander Benifand
}

Right after the decision (March 20, 1995) of U.S. President Bill Clinton to go to Moscow on May ninth, to attend a Russian commemoration of the 50th anniversary of the allied victory in Europe and to hold talks with Russian president Boris Yeltsin, Moscow has escalated the bloody operation in Chechnya in the area of Argun and against towns and villages which are in the southwest area of Grozny. Russian troops have been conducting a reign of terror in the parts of Chechnya brought under their control, routinely engaging in gross violations of basic rights. Ironically, just a few weeks before the decision of the American President, the Secretary of State, Christopher, said it would be unlikely for President Clinton to go to Moscow so long as Russian troops were still on the offensive in Chechnya.

Why did this war begin? Some analysts believe that there are several reasons for the war in Chechnya: political, economic, Mafia type division of territory and others. But for many analysts it seems that after the bloody October 1993, when most of the Western Governments and internal Russian political forces applauded the dispersal of Parliament, Yeltsin thought that a successful operation in the Chechen Republicmight upgrade his own political standing in Russia. He had to demonstrate to Russians that he is a strong President and very concerned with the territorial integrity of Russia. He tried to play the Chechen card because he knew that Chechens and other people from the North Caucasus are not so popular in Russia. There is a very strong racist mentality, among some groups of people, that Caucasians are 'blacks' in Russia.

Dr. Alexander Benifand is a researcher at Centre Refugee Studies, York University.

\section{Human Rights Violations}

A report by the Russian president's commission on human rights suggested that as many as 24,400 civilians have died since the war in the separatist republic began on December 11, 1994. But the figure-so high that the researcher who came up with it likened the Chechen conflict to the slaughter of Polish civilians during World War I-was questioned even by the head of the human rights commission, Sergei A. Kovalyov. He said in an interview that although the exact number of dead is not known, it could be as high as 30,000 . "All I can say for now," he added, "is that the number is in the tens of thousands." 1 The official count had previously been under 500 , though many officials have openly said that as many as 4,000 Russian soldiers have already died. By way of contrast, fewer than 13,000 Russian soldiers were killed in a decade of fighting in Afghanistan.

There is a serious violation of human rights there. The local director of an American human rights group, says the bulk of the abuse has been committed by Russian forces, but both sides are guilty of violations. The human rights investigator showed that the Chechen violations appear to have come about recently, during the rebels retreat from the capital Grozny. Jonas Bernstein, the Moscow director of the U.S. based Freedom House, reported that the Russian Prisoners of war were apparently severely beaten as they were moved out of the capital. Russian P.O.W. mothers, who were able to see their sons in towns like Shali, reported signs of abuse. Mr. Bernstein met with a group of Russian prisoners of war in Shali who appeared healthy and unharmed. But he says he was not given access to all the men held there.

Mr. Bernstein says the abuse of Chechen prisoners by Russian forces has been much more systematic, but appears to be lessening. In addition to the beatings, the choice of men Russian soldiers have detained appears highly arbitrary. Few, if any of the fighters on the Chechen side are ethnic Russians, but the mission reports one third of the 350 people detained in Mozdok were ethnic Russians.

According to Mr. Bernstein, the worst aspect of the war is what he calls the blatant disregard by Moscow for the lives of civilians. He notes Chechen fighters, or potential fighters, are in villages and towns across Southern and Western Chechnya and Russian forces appear determined to bomb and shell them out of their positions. This means, the human rights investigator says, innocent men, women and children will continue to be killed in staggering disproportion to Chechen fighters.

In Petropavlovskaya, prisoners were hustled off to a small rise overlooking the nearby Soonja River, and one managed to escape. The others were beaten with rifle butts and forced to their knees. In less than a minute they were dead. "The soldier shot them, pushed their bodies down the hill, and sprayed them again with bullets as they were rolling," reported Shahsuddin Baisugurov, a retired police officer who said he witnessed the slaughter from his house nearby. Adding to the horror, Baisugurov said, one soldier video-taped the killings.

Ms. E. Bonner, the widow of famed Soviet dissident Andrei Sakharov, is introducing a resolution at the Geneva meeting on behalf of the New Yorkbased International League for Human Rights. She was scathingly critical of Russia's conduct in the war, and she said Moscow must be forced to seek peace in Chechnya.

Mr. Kovalyov showed no hesitation in repeating his criticism of Russian actions in the breakaway region. The

Refuge, Vol. 14, No. 10 (March 1995) 
Russian army and interior ministry forces, he said, are guilty of massive human rights violations, including attacks against civilians, torture, and extrajudicial killings. He said Russian forces have mistreated anyone even suspected of sympathizing with the Chechen separatists.

Antiwar activist Maria Kirbasova told Interfax on February 14, that the Soldiers' Mothers Committee ${ }^{2}$ intended to sue the organizers of the Chechen operation in the International Court of Justice in The Hague. Also, some top Russian legal professionals have reportedly agreed to cooperate with the public tribunal set up in Moscow earlier this year to put the initiators of the war on trial.

Russia's chief prosecutor has said he will file criminal charges against all deserters, with punishment of five to ten years in jail or death by firing squad. But the group's lawyers say they believe the war violates the Russian constitution, which forbids using the armed forces to put down internal rebellions unless the president declares a formal state of emergency.

Even the leaders of the Government of National Revival, the puppet Chechen regime installed by Moscow, blame the Russians for not acting fast enough or firmly enough to stop the abuses. They say their fragile credibility with the Chechen people is further undermined by the crimes of Russian soldiers. The Chechen opposition Provisional Council issued a statement condemning "barbaric, senseless, and cruel" bombardments of civilian areas.

\section{Refugees}

Amnesty International has reported that people detained by the Russians have been mistreated. It says Russian forces have also shot civilians trying to flee Chechnya. Amnesty says it is concerned that Russian officials do not appear interested in investigating the abuses or in punishing those responsible for them. Since the war in Chechnya erupted last December, UN and Red Cross officials estimate that more than 300,000 civilians have fled to neighbouring regions and 250,000 others have been displaced inside the country.

Only neighbouring Dagestan took 100,000 Chechen refugees. There is $a$ is a lack of housing and outbreaks of disease due to poor sanitation and overcrowding are common. The Dagestani Government, faced with a critical shortage of housing for the refugees, has decided to set up tent camps for the latest arrivals near the border. If the exodus from Chechnya continues, it will become increasingly difficult for the UN and other agencies to cope with the situation.

Returning to the possibility of disintegration of Russia, U.S. Defence Secretary William Perry said, "I think, there is a danger that the actions that the government has taken there could destabilise, could cause instabilities within Russia." Istvan Gyarmati, the O.S.C.E. diplomat, told reporters in Moscow at the end of March 1995 that: "It seems the danger of the war spreading to the neighbouring republics is much greater than at the time of my last visit one and half months ago." Gyarmati warned that, as Chechen fighters retreated towards the borders of Ingushetia and Dagestan, the chances increased that the fighting would spill over into those areas as well.

In Ufa, Bashkortostan, an autonomous Muslim republic in central Russia, the regional President says Mr. Yeltsin refused his offer on three occasions to mediate talks between Russia and Chechnya. He warns that the most dangerous problem facing the country is relations between the centre and the republics, but that Moscow fails to understand this key point. The centre continues to dictate in the Soviet fashion and even Bashkortostan's special status is seen by many in Moscow as extremism-this despite its stated desire to stay in the federation. Russia may be using the Chechen war to intimidate other republics in the Russian Federation.

\section{The Future of Chechnya}

Chechens have always been a proud, fervently independent people. They fought a 30-year war against Czarist armies in the last century before being forced into Russia's orbit. Soviet dictator Josef Stalin deported all 800,000 of them to Kazakhstan in 1944 for alleged Nazi collaboration. The controversial Dudayev declared independence in 1991, after being elected Chechnya's first president. Russia says the elections were illegal. It's not so, said the President of Bashkortostan, $M$. Rachimov, the largest Russian semiautonomous republic.

M. Shamiev, the President of the semi-autonomous republic of Tatarstan, predicted that Russia will forcibly integrate Chechnya into its federation after a military defeat of the rebel region's forces and it will take an enormous amount of time for the Russians to win back the confidence of the Chechen people. Shaimiev said Russia might not maintain a military occupation, but it would impose a political power structure and use internal police and intelligence services to keep control. President of Chechnya, D. Dudaev, predicted that the war could be longer than the war in Afghanistan and Russia could not win its campaign militarily and should start immediate negotiations.

\section{Political Turmoil in Russia}

The war in Chechnya has created a very dark political turmoil in the country. "Russia is now governed by a military-civilian junta disguised as the National Security Council," said Alexei Manannikov, deputy chairman of the upper house of Parliament's international affairs committee. "The Security Council has no right running this country. If it continues, Russia will be ripe for an authoritarian dictatorship."

A few years ago, when Yeltsin came to power, he used democratic slogans because it was so important for the mentality of the liberal intelligentsia who helped him in his conflict with Gorbachev. And after 1991, he has moved step by step towards the right wing camp. Yeltsin, being a populist, always moved together with the opinion of masses. S. Kovalyov said that 
Russia cannot continue along the path of democratic reform if it pursues what he called this dirty war in Chechnya.

"This has not been like Afghanistan," said Major General Serge Zdorikov, a Defense Ministry political officer "It is far more horrible and debilitating than that." Gorbachev said the war in Chechnya will cost Russia dearly. Not just in economic terms, but especially politically and morally. Those in power have put themselves in a corner. Yadviga Yuferova, the political editor of Izvestia, said in an interview: "The government is closing in again. They won't speak the truth. It's all become lies again. We know they can't censor us now-our society has come too far for that. But they can do other things that will close us down." She also said, Mr. Yeltsin could in a stroke of his pen, raise the cost of newsprint to a level nobody could afford. "It's different than the old methods," she said sadly. "But the results might be the same."

\section{Western Response}

Mrs. Bonner was critical of the international response to the Chechen war. She said that the world reaction in the first few weeks of the war was absolutely inadequate, adding that many Western leaders seemed to share what she termed the short-sighted view that the fighting would be over quickly. She was also passionately dismissive of those who contend it is an internal conflict.

The 33-Nation Council of Europe has suspended membership talks with Russia until Moscow stops attacking its breakaway republic of Chechnya. Since December 11, Russian troops have killed thousands of Chechens, despite obvious internal conflict over the matter in Moscow. A Belgian newspaper stated that NATO cannot now accept that Russia sees the Chechnya crisis purely as an internal matter, and warned that Russia could isolate itself if it maintains its hard-liner stance in Chechnya.

Chancellor Helmut Kohl of Germany (who is usually a firm supporter of Mr. Yeltsin), after the pressure from opposition parties, said that "breaches of human rights are not an internal matter." George Soros, an investor who has funnelled billions of dollars into the economies of Eastern Europe and the former Soviet Union since Communism collapsed, said that today Russia's politics and economy are far too fragile to withstand much more of this war. "I am very disturbed by the prospects in Russia," Mr. Soros said at a news conference. "I do see Chechnya as a part of a campaign to disrupt relations with the West and re-establish a closed society."

\section{The Lessons of Chechnya}

What kind of lessons follow from the war in Chechnya?

1. The first and main lesson after the war in Chechnya is that the world community cannot do much to protect people around the world.

2. After the war the World community remained selfish and primarily concern with self interest, not the interest of other populations.

3. The same psychology exists today as before and after the Second Word War: indifference to the violations of human rights and abuses of the people if it is in the global interest (like safety of nuclear weapons). Unfortunately people will never learn from the lessons of the past if they do little to prevent such violations (it will give more validation and incentive for further human rights abuses and even new wars. For example, last fall the majority of Western officials applauded Mr. Yeltsin when he crushed down the Russian Parliament and received almost dictatorial power.)

4. When the Soviet Union was collapsing and nations that had never even dreamed about independence, like Kirgistan for example, in one day became an independent countries the Western nations did not respond with any significant support to that. All of these new contries are attempting to build democracy but have very little experience with it and in order to succeed, they need assistance.

\section{Notes}

1 Kovalyov, a well-known anti-Soviet dissident, has been a passionately outspoken critic of the invasion of Chechnya, and spent several weeks in Grozny trying to bring attention to the death and suffering there. He has been accused by government officials of inflating civilian casualty figures and ignoring Chechen war crimes.

2 The Russian Committee of Soldiers' Mothers, who have achieved international recognition for their opposition to the brutal war in Chechnya, have been awarded the 1995 Sean MacBride Peace Prize by the International Peace Bureau in Geneva. The soldiers' mothers have been active, assisting family members to recover the bodies of those killed in Grozny and establishing the whereabouts of those held as prisoners of war. They have also engaged in direct contacts with Chechen mothers. Since its foundation in 1989 , the group has devoted itself with energy to the cause of human rights in the Russian armed forces.

\section{References}

Gallagher, James P. 1995. "Crazy with fear, Russian army lashes out at civilians." International Herald Tribune, February 12.

Kaplan, Fred. 1995. "Russia's Worried Moms March Their Sons Back From Chechnya." January 25.

Omri Daily Digest, February1995, No. 33, Part I.

Omri Daily Digest, March 29, 1995, No. 63, Part I.

Reuter Reports: Moscow January 14, 1995; Athens, January 13, 1995; New Delhi, January 13, 1995; The Hague, January 13, 1995; London, February 9, 1995.

"Russian Soldiers' Mothers Awarded Peace Prize." Written 3:19 PM Jan 18, 1995 by sgastete@u.washington.edu in igc:misc. activism.

Specter, Michael. 1995. "For Yeltsin, a Costly 'Victory.'" International Herald Tribune, January 20, 1995; and The New York Times, January 20, 1995.

Specter, Michael. 1995. "Russians and Rebels Agree to a Cease-Fire." The New York Times, January 18.

Stanley, Alessandra. 1995. "Chechnya toll: 'Tens of thousands." The New York Times, February 21.

Toronto Star, The. March 29, 1995. "Refugees flood into Dagestan from Chechnya."

Voice of America Reports: January 18, 1995; February 6, 1995; February 8, 1995; February 10, 1995; February 16, 1995; March 8, 1995; March 20, 1995; March 28, 1995.

Workers World , February 16, 1995. 